\title{
OPTIMIZATION OF THE PRODUCTION PROCESS MODEL USING PATTERN SEARCH METHOD
}

\author{
ANNA LANDOWSKA \\ Faculty of Management and Economics of Services, University of Szczecin, POLAND \\ e-mail: anna.landowska@wzieu.pl
}

\begin{tabular}{l|l} 
RECEIVED & 6 November 2018 \\
ACCEPTED & 3 December 2018 \\
JEL & \\
CLASSIFICATION & C45, C61, D24, E23
\end{tabular}

KEYWORDS dynamic linear model, pattern search, quality management, production management

ABSTRACT The paper presents the use of the pattern search method for optimization of the plant production process. The described approach can be used for management of production and for increasing the quality of products obtained during the production process. The presented optimization method can be applied in various fields of service economics, such as: quality management, financial management, production management and many others. In the production process the maximization of income with constraint conditions is taken into account. Proper management of plant production is based on the correct rotation of plants in order to obtain the highest crop, keeping the soil in good condition.

\section{Introduction}

The optimization process is used, for example, to achieve the maximum or minimum of the considered value. Optimization is used in many areas of management, e.g. quality, knowledge, marketing, logistic, finance, innovation, information, and so on. There are many optimization methods. The article presents the application of the pattern 
search method for management of the plant production. This method was used for optimization of the agricultural income to plan the structure of the dynamic plant production model.

Dynamic models are often used in many areas of management and production. For example, the use of dynamic models for the management of forest plantations can be found in the papers (Hartmann, 1976, pp. 5258; Kennedy, 1986; Cacho, Hean, 2004, pp. 139-163). The use of dynamic models can also be found in problems related to urbanized areas. R. Jiang, Q. Wu, Y. Zhu (2001, pp. 345-348) depict a dynamic model describing traffic, whereas Sh. Gui, Q. Zhu, L. Lu (2005, pp. 265-269) use a system dynamic model to present the logistics system.

Problems related to dynamic programming used to construct a dynamic model were described, among others, in the following papers (Bellman, 1967; Findeisen, Szymanowski, Wierzbicki, 1972; Grabowski, 1980; Lew, Mauch, 2007; Robinett, Eisler, Wilson, Hurtado, 2005; Stadnicki, 2006). T. Trzaskalik (1990, 1998) also describes multicriterial dynamic programming.

The pattern search method, which was used in the paper to solve the dynamic production model, has been known since the 1950s. This method has been developed because it does not require the knowledge of the function $f$ gradient to solve the problem. Often, knowledge of the gradient $\nabla f(x)$ may be difficult or impossible, and methods that determine the approximate value of the gradient give a result that may bear a risk of a serious error, which in turn will result in an optimization error.

The first formal definitions are given in paper (Hooke, Jeeves, 1961) calling the method "direct search", whereas pattern search is depict as its modification and a subclass of direct search methods.

The pattern search method is described and analyzed in detail in 1997 by (Torczon, 1997). R.M. Lewis and V. Torczon (1999) in show the development of a method for the optimization of functions with constraints (Lewis, Torczon, 1999; 2002) as well as linear limitations (Lewis, Torczon, 2000). The research of the pattern search method was also performed by (Audet, Dennis Jr., 2003; Lewis, Torczon, 2000).

The theory of the pattern search method presented in the article was taken from the works (Torczon, 1997; Lewis, Torczon, 1999, 2000, 2002). Problems concerning the optimization of the problem with limitations are described in (Conn, Gould, Toint, 1991, 1997).

\section{Planning model of the structure of plant production}

In order to present the analytical form of the dynamic planning model of the plant production structure, let us assume the following denotations:

$t=1,2, \ldots, T$ - period number, $j=1,2, \ldots, n$ - number of decision variables,

$i=1,2, \ldots, m-$ number of restrictive conditions regarding, e.g., land area, structure of sowing, production for sale, fertilization and labor consumption,

$x_{j}^{t}-$ decision variable in period $t$,

$a_{i j}^{t}-i$-th unit coefficient of expenditure on $j$-th type of activity in period $t$,

$b_{i}^{t}-$ limit of the $i$-th limiting condition in period $t$,

$u_{j}^{t}$ - the lower limit of the $j$-th variable in period $t$,

$v_{j}^{t}$ - the upper limit $j$-th variable in period $t$,

$c_{j}^{t}$ - agricultural income of $j$-th type of activity in the period $t$. 
With the above denotations, the maximum size of agricultural income for $n$ types of activity in $T$ periods will be expressed by the formula:

subject to:

$$
F\left(x_{j}^{t}\right)=\sum_{t=1}^{T} \sum_{j=1}^{n} c_{j}^{t} x_{j}^{t} \rightarrow \max ,
$$

$$
\begin{gathered}
\sum_{t=1}^{T} \sum_{j=1}^{n} a_{i j}^{t} x_{j}^{t} \leq b_{i}, i=1,2, \ldots, \mathrm{m} \\
\text { and } u_{j}^{t} \leq x_{j}^{t} \leq v_{j}^{t}, x_{j}^{t} \geq 0 .
\end{gathered}
$$

\section{Pattern search method}

For the pattern search algorithm without constraints (Torczon, 1997, p. 4), the task is to minimize the function $\min f(x)$. To find the maximum value, one should run the optimization process for function- $f(x)$. In the $k$-th iteration we have the assumed position $x_{k} \in R^{n}$ and the length of the iteration step $\Delta_{k}>0$. Then, we analyze the points $x_{+}=x_{k} \pm \Delta_{k} e_{i}$, where $i \in\{1,2, \ldots, n\}$, until we find one $x_{+}$, which satisfies the condition $f\left(x_{+}\right)<f\left(x_{k}\right)$.

The first part of the name of the "pattern" method comes from a set of possible points $x_{+}$to be analyzed (Figure 1). If we do not find $x_{+}$satisfying the condition $f\left(x_{+}\right)<f\left(x_{k}\right)$, we reduce $\Delta_{k}$ by half and continue calculations. Otherwise, we leave the step length unchanged, assuming $\Delta_{k+1}=\Delta_{k}$ and $x_{k+1}=x_{+}$, or we can double the length of the iteration step $\Delta_{k}>0$ and continue the search, provided that increasing the step length is justified. We repeat the iteration described above until we find that $\Delta_{k}$ is appropriate.

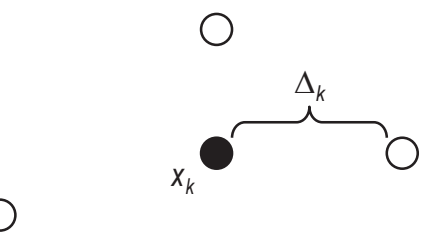

$\bigcirc$

Figure 1. A set of points, among which one finds a point used in the next iteration in pattern search, a case without constraints Source: Lewis, Torczon (2000), p. 3.

In case of optimization with linear constraints, we need to expand the information on a sufficient set of searches; in case of the unlimited set, this set was included in the whole set $R^{n}$. The information about the problem should now be clearly defined, such as the scope and shape of the linear constraints. In the problem with constraints, the scope of the search is denoted by $\Omega$ (Figure 2). 


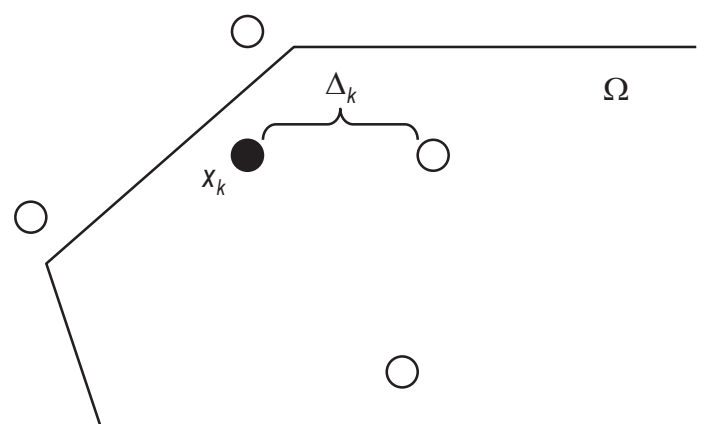

Figure 2. A set of points with the selected optimization area $\Omega$, among which the point used in the next iteration is found, the pattern search optimization case with linear constraints

Source: Lewis, Torczon (2000), p. 4.

To define a sample (pattern), one must specify two components, the basic matrix $B \in R^{n \times m}, B \neq I$, and generated matrix $C_{k} \in Z^{n \times p}$, where $p>1 n$. We divide the generated matrix into the following components:

$$
C_{k}=\left[\begin{array}{lll}
M_{k} & -M_{k} & L_{k}
\end{array}\right]=\left[\begin{array}{ll}
\Gamma_{k} & L_{k}
\end{array}\right] .
$$

It is required that $M_{k} \in M \subset Z^{n \times n}$, where $M(M \neq I)$ is a finite set of matrices and $L_{k} \in Z^{u ̈ \times u ̈ ~-~}$ and contains at least one zero column. The sample (pattern) $P_{k}$ is then defined as the columns of the matrix $P_{k}=B C_{k}$.

Generalized pattern search algorithm for unlimited constraints. Let there be data $x_{0} \in R^{n}$ and $\Delta_{k}>0$. For $k=0,1, \ldots$ we have:

Step 1. We calculate $f\left(x_{k}\right)$.

Step 2. We set a step $s_{k}$.

Step 3. We calculate $\rho_{k}=f\left(x_{k}\right)-f\left(x_{k}+s_{k}\right)$.

Step 4. If $\rho_{k}>0$ then $x_{k+1}=x_{k}+s_{k}$ else $x_{k+1}=x_{k}$.

Step 5. Upgrading $C_{k}$ i $\Delta_{k}$.

For the case of pattern search optimization with linear constraints, in Step 2 of the generalized algorithm the following conditions must be met:

$$
\begin{gathered}
s_{k} \in \Delta_{k} P_{k} \equiv \Delta_{k}\left[\begin{array}{ll}
\Gamma_{k} & L_{k}
\end{array}\right], \\
\left(x_{k}+s_{k}\right) \in \Omega, \\
\text { If } \min \left\{f\left(x_{k}+y\right) \mid y \in \Delta_{k} \Gamma_{k} \wedge\left(x_{k}+y\right) \in \Omega\right\}<f\left(x_{k}\right) \text { then } f\left(x_{k}+s_{k}\right)<f\left(x_{k}\right) .
\end{gathered}
$$

The steps of the pattern search algorithm for the case with constraints resemble those in the case without constraints, but the area should be taken into account, so the initial values have the form: $x_{0} \in \Omega, \Delta_{k}>0$ and $k=0,1, \ldots$ 


\section{Results}

This section presents the results of optimization of the dynamic plant production model obtained with pattern search method.

The optimization results were obtained using a program written in Matlab with the built-in pattern search function. The optimization model, called parallel model, used in the paper in details is described in (Landowska, Landowski, pp. 48-50, 2012; Landowska, 2017, p. 6). This model is one-stage, in which individual periods are related to binding conditions, so that crop rotation is taken into account. The initial vector for this model was the null vector.

In the optimization process, the value of the objective function (agricultural income) was obtained at PLN 96,083.41. In particular periods, the size of agricultural income amounted to: PLN 27,460.66, PLN 20,554.67, PLN 23, 935.19 and PLN 24,132.89.

The detailed sowing structure obtained by the pattern search method is shown in Figure 3.

Figure 3 shows that in four periods the most stabilized were rapeseed crops, for three periods they amounted to $1.84 \mathrm{ha}$, and in the second period $1.71 \mathrm{ha}$. The largest area in particular periods included rye sowing - from 2.96 ha in the third period to 3.76 ha in the second period. The next cereal crop was wheat with sowing from 1.71 ha in the third period to 2.32 ha in the first period. No other crops were added to the optimal solution in any year. In case of other plants, their sowing area undergoes quite significant rotations.

Table 1 presents the results of pattern search method optimization of a dynamic parallel model of crop production of a farm, divided into four sown areas and four production periods. It can be seen that the areas have not been evenly divided. For this production model, area 3 ( $3.76 \mathrm{ha}$ ) was the largest area. The first area was $3.38 \mathrm{ha}$, and the fourth and second were 3.07 ha and 2.96 ha, respectively.

Table 1. Crop rotation of agricultural production in four periods obtained with PS method

\begin{tabular}{|c|c|c|c|c|}
\hline & Area 1 & Area 2 & Area 3 & Area 4 \\
\hline Period I & $\begin{array}{c}\text { oats } 1.54 \mathrm{ha}, \\
\text { potatoes } 0.43 \mathrm{ha}, \\
\text { beets } 1.41 \mathrm{ha}\end{array}$ & $\begin{array}{l}\text { wheat } 2.32 \text { ha, } \\
\text { barley } 0.64 \text { ha }\end{array}$ & $\begin{array}{l}\text { triticale } 1.92 \mathrm{ha} \text {, } \\
\text { rape } 1.84 \mathrm{ha}\end{array}$ & $\begin{array}{c}\text { rye } 3.07 \text { ha, } \\
\text { other crops } 0 \text { ha }\end{array}$ \\
\hline Period II & $\begin{array}{l}\text { wheat } 2.15 \text { ha, } \\
\text { barley } 1.23 \text { ha }\end{array}$ & $\begin{array}{l}\text { triticale } 1.25 \mathrm{ha} \text {, } \\
\text { rape } 1.71 \mathrm{ha}\end{array}$ & $\begin{array}{l}\text { rye } 3.76 \text { ha, } \\
\text { other crops } 0 \text { ha }\end{array}$ & $\begin{array}{c}\text { oats } 1.23 \mathrm{ha}, \\
\text { potatoes } 0.43 \mathrm{ha}, \\
\text { beets } 1.41 \text { ha }\end{array}$ \\
\hline Period III & $\begin{array}{l}\text { triticale } 1.54 \text { ha, } \\
\text { rape } 1.84 \text { ha }\end{array}$ & $\begin{array}{l}\text { rye } 2.96 \text { ha, } \\
\text { other crops } 0 \text { ha }\end{array}$ & $\begin{array}{c}\text { oats } 2.05 \mathrm{ha}, \\
\text { potatoes } 0.81 \text { ha, } \\
\text { beets } 0.9 \text { ha }\end{array}$ & $\begin{array}{l}\text { wheat } 1.71 \text { ha, } \\
\text { barley } 1.36 \text { ha }\end{array}$ \\
\hline Period IV & $\begin{array}{c}\text { rye } 3.38 \text { ha, } \\
\text { other crops } 0 \text { ha }\end{array}$ & $\begin{array}{c}\text { oats } 1.12 \text { ha, } \\
\text { potatoes } 0.15 \text { ha, } \\
\text { beets } 1.69 \text { ha }\end{array}$ & $\begin{array}{l}\text { wheat } 2.21 \text { ha, } \\
\text { barley } 1.55 \text { ha }\end{array}$ & $\begin{array}{c}\text { triticale } 1.23 \text { ha, } \\
\text { rape } 1.84 \text { ha }\end{array}$ \\
\hline
\end{tabular}

Source: own study. 
Period I
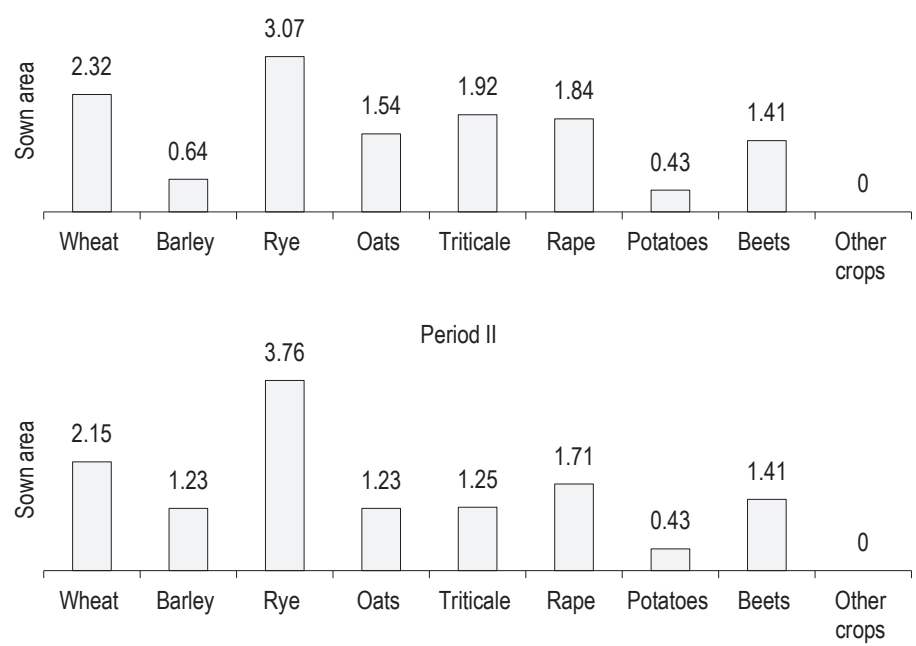

Period III
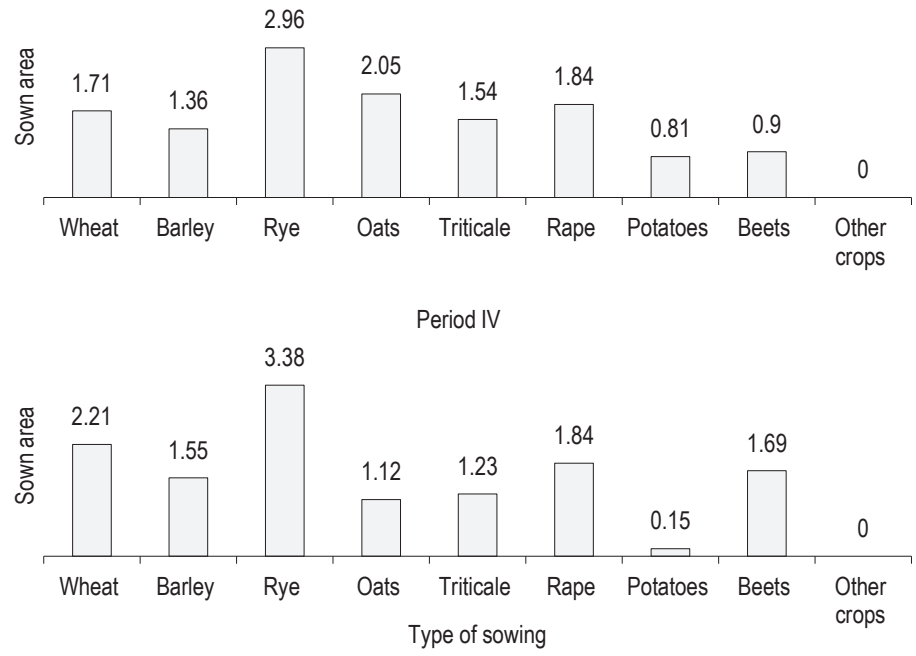

Figure 3. Plant production structures obtained with pattern search method (ha)

Source: own study.

\section{Conclusions}

In the paper the usage of the pattern search method for optimization of the dynamic production model was described. The obtained results show that it is possible to obtain the maximum value of agricultural income, taking into account appropriate plant rotation. In this paper the application of the pattern search method to dynamic linear model was presented but considered method can also optimize static or dynamic models with linear or nonlinear 
constraints. The pattern search method can also be used to optimize models related to the various management processes.

\section{Referencess}

Audet, Ch., Dennis Jr., J.E. (2003). Analysis of Generalized Pattern Searches. SIAM Journal on Optimization, 13 (3), 889-903.

Bellman, R.E. (1967). Programowanie dynamiczne. Warszawa: PWN.

Cacho, O., Hean, R. (2004). Dynamic optimization for evaluating externalities in agroforestry systems: An example from Australia. In: J.R.R. Alavalapati, D.E. Mecer (eds.), Valuing Agroforestry Systems. Methods and Applications (pp. 139-163). New York: Kluwer Academic Publishers.

Conn, A.R., Gould, N.I.M., Toint, Ph.L.A (1991). A Globally Convergent Augmented Lagrangian Algorithm for Optimization with General Constraints and Simple Bounds. SIAM Journal on Numerical Analysis, 28 (2), 545-572.

Conn, A.R., Gould, N.I.M., Toint, Ph.L.A. (1997). Globally Convergent Augmented Lagrangian Barrier Algorithm for Optimization with General Inequality Constraints and Simple Bounds. Mathematics of Computation, 66 (217), 261-288.

Findeisen, W., Szymanowski, J., Wierzbicki, A. (1972). Teoria i metody obliczeniowe optymalizacji. Warszawa: PWN.

Grabowski, W. (1980). Programowanie matematyczne. Warszawa: PWE.

Gui, Sh., Zhu, Q., Lu, L. (2005). Area Logistics System Based on System Dynamics Model. Tsinghua Science and Technology, 10 (2), 265-269.

Hartman, R. (1976). The harvesting decision when a standing forest has value. Economic Inquiry, 14, 52-58.

Hooke, R., Jeeves, T.A. (1961). "Direct search" solution of numerical and statistical problems. Journal of the ACM, 8 (2), 212-229.

Jiang, R., Wu, Q., Zhu, Z. (2001). A new dynamics model for traffic flow. Chinese Science Bulletin, 46 (4), 345-348.

Kennedy, J.O.S. (1986). Dynamic programming: applications to agriculture and natural resources. London: Elsevier Applied Science.

Landowska, A. (2017). Zastosowanie klasycznego algorytmu genetycznego do rozwiązywania dynamicznych modeli produkcji. Folia Pomeranae Universitatis Technologiae Stetinensis. Oeconomica, 337 (88), 5-12.

Landowska, A., Landowski, M. (2012). Zastosowanie wybranych modeli optymalizacji dynamicznej struktury produkcji roślinnej w przeciętnym gospodarstwie rolnym. Folia Pomeranae Universitatis Technologiae Stetinensis. Oeconomica, 297 (68), 47-54.

Lew, A., Mauch, H. (2007). Dynamic Programming. Berlin Heidelberg: Springer-Verlag.

Lewis, R.M., Torczon, V. (1999). Pattern Search Algorithms for Bound Constrained Minimization. SIAM Journal on Optimization, 9 (4), 1082-1099.

Lewis, R.M., Torczon, V. (2000). Pattern Search Methods for Linearly Constrained Minimization. SIAM Journal on Optimization, 10 (3), 917-941.

Lewis, R.M., Torczon, V. (2002). A Globally Convergent Augmented Lagrangian Pattern Search Algorithm for Optimization with General Constraints and Simple Bounds. SIAM Journal on Optimization, 12 (4), 1075-1089.

Robinett, R.D., Eisler, G.R., Wilson, D.G., Hurtado J.E. (2005). Applied Dynamic Programming for Optimizations of Dynamical System. Philadelphia: SIAM.

Stadnicki, J. (2006). Teoria i praktyka rozwiązywania zadań optymalizacji. Warszawa: WNT.

Torczon, V. (1997). On the Convergence of Pattern Search Algorithms. SIAM Journal on Optimization, 7 (1), 1-25.

Trzaskalik, T. (1990). Wielokryterialne dyskretne programowanie dynamiczne: teoria i zastosowanie w praktyce gospodarczej. Katowice: Akademia Ekonomiczna im. Karola Adamieckiego.

Trzaskalik, T. (1998). Multiobjective analysis in dynamic environment. Katowice: Akademia Ekonomiczna im. Karola Adamieckiego.

Cite this article as:. Landowska, A. (2018). Optimization of the production process model using pattern search method. European Journal of Service Management, 4 (28/1), 165-171. DOI: 10.18276/ejsm.2018.28/1-21. 